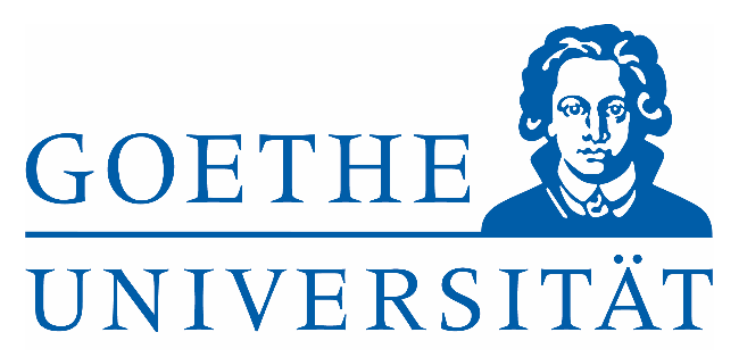

FRANKFURT AM MAIN

\title{
Faculty of Law
}

Research Paper No. 7/2020

\section{Virtual Patent Networks and Their Network Effects}

\author{
Alexander Peukert* \\ Forthcoming in: Christine Godt/Matthias Lamping (eds), liber amicorum Hanns Ullrich \\ Proposed citation: Alexander Peukert, Virtual Patent Networks and Their Network Effects, Research \\ Paper of the Faculty of Law of the Goethe University Frankfurt/M. No. 7/2020, para.
}

Abstract: On the basis of the economic theory of network effects, this article provides a novel explanation of the so-called patent paradox, i.e. the question why the propensity to patent is so strong when the expected average value of most patents is low. It demonstrates that the patent system of a country resembles a telephone network or a social media platform. Patents are perceived as nodes in a virtual network that, as a whole, exhibits network effects. It is explained why patents are not independent of other patents but that they complement each other in several ways both within and beyond markets and fields of technology, and that patents thus create synchronization value over and above individual interests of patent holders in exclusivity. As a consequence, the more patents there are, the more valuable it is to also seek patents, and vice versa. Since patents thus display increasing returns to adoption, the willingness to pay for the next patent slopes upwards. This explains why, after a phase of early instability and a certain tipping point, many countries' patent systems expanded quickly and eventually became a rigid standard ("lock-in"). The concluding section raises the question what regulatory measures are suitable to effectively address the ensuing anticommons effects.

\footnotetext{
* Dr. iur., Professor für Bürgerliches Recht und Wirtschaftsrecht am Fachbereich Rechtswissenschaft der Goethe-Universität Frankfurt am Main.
} 
"The reasons for the rise in patent numbers are not entirely clear. ... However, they do not simply correlate with more innovation ..., but possibly also with (new) variations in the function and use of patents ..."

\section{The Patent Paradox Puzzle}

1 One of the fascinating features of intellectual property (IP) law is the rapid and consistent growth of the numbers: of states being bound by IP treaties, of IP laws, of protectable subject matter, and of rights applied for and granted. In addition to this quantitative growth, the scope and thus quality of IP rights (IPRs) has expanded too. In the prefatory quote, Hanns Ullrich addresses the well-documented fact of increased patenting. ${ }^{2}$ Patent thickets, i.e. overlapping sets of patent rights requiring that those seeking to commercialize new technology obtain licenses from multiple patentees, have also achieved impressive sizes, and they occur more frequently. ${ }^{3}$

2 Whereas the growth in absolute patent numbers is evident, its reasons are unclear and hotly debated. Ullrich indicates that the surge in patenting is not simply an expression of more innovation, as the mainstream justification of patents would suggest. And indeed, economic studies have not been able to establish a correlation between patenting activity and research and development (R\&D) investment. There is no statistically significant effect from more patents/patent thickets on R\&D. ${ }^{4}$ Instead, a case study of the U.S.

\footnotetext{
${ }^{1}$ Hanns Ullrich, 'The Political Foundations of TRIPS Revisited' in Hanns Ullrich and others (eds), TRIPS plus 20. From Trade Rules to Market Principles (Berlin/Heidelberg: Springer 2016), 112.

${ }^{2}$ Georg v Graevenitz, Stefan Wagner and Dietmar Harhoff, 'Incidence and Growth of Patent Thickets: The Impact of Technological Opportunities and Complexity' (2013) 61(3) The Journal of Industrial Economics 521, 521-2 with further references; Stefano Comino, Fabio M Manenti and Nikolaus Thumm, 'The Role of Patents in Information and Communication Technologies: A Survey of the Literature' (2019) 33(2) Journal of Economic Surveys 404, 406-7.

${ }^{3}$ See Carl Shapiro, 'Navigating the Patent Thicket: Cross Licenses, Patent Pools, and Standard Setting' in Adam B Jaffe, Josh Lerner and Scott Stern (eds), Innovation Policy and the Economy (Chicago: University of Chicago Press 2001), vol 1, 119; Graevenitz, Wagner and Harhoff (n 2), at 559. Bronwyn H Hall and others, 'A Study of Patent Thickets' (Intellectual Property Office Research Paper No 2, 2013), 3; Case C170/13 Huawei Technologies [2015] ECLI:EU:C:2015:477, para 47 (the telecommunications standard at stake is composed of more than 4.700 standard essential patents); Jonathan M Barnett, 'From Patent Thickets to Patent Networks: The Legal Infrastructure of the Digital Economy' (2014) 55 Jurimetrics J 1, 153.

${ }^{4}$ Jérôme Danguy, Gaétan de Rassenfosse and Bruno van Pottelsberghe de la Potterie, 'On the origins of the worldwide surge in patenting: an industry perspective on the R\&D-patent relationship' (2014) 23(2) Industrial and Corporate Change 535, 560 ("R\&D explains only a small share of the variance in patent
} 
semiconductor industry between 1982 and 1992 found that patenting per million real R\&D dollars doubled. ${ }^{5}$ Neither is there a correlation between patenting and general economic growth as measured by the gross domestic product (GDP). ${ }^{6}$ Note that I speak of correlation. If there is no correlation, claims that causality runs from patents to innovation and in a virtuous circle back to more patents are even more implausible.

3 Moreover, "[n]ot all inventions are patentable, not all inventions are patents and the inventions that are patented differ greatly in 'quality', in the magnitude of inventive output associated with them." Most firms do not rely on patents as the primary mechanism to appropriate innovation returns. ${ }^{8} \mathrm{~A}$ substantial share of $\sim 40 \%$ of patents remain unused. These patented technologies are not implemented in a product, nor are the patents licensed. ${ }^{9}$ Only about $10 \%$ of all patents reach an age of ten years and are thus considered of relevant economic value. In other words, economists consider $90 \%$ of all

filings"); Florian Jell, Joachim Henkel and Martin Wallin, 'Offensive Patent Portfolio Races' (2017) 50 Long Range Planning, 531, 544 ("We could clearly show that the observed increases in patenting were not mainly driven by heightened inventive activity and that patenting rates are, within boundaries, somewhat arbitrary."); Mahdiyeh Entezarkheir, 'Patent thickets, defensive patenting, and induced R\&D: an empirical analysis of the costs and potential benefits of fragmentation in patent ownership' (2017) 52 Empir Econ 599, 603; Mark A Lemley, 'The Surprising Resilience of the Patent System' (2016) 95 Tex L Rev 1, 36 ("The growth rate of R\&D was highest in the late 1970s and early 1980s, when patents were weak and the number of patents was not growing dramatically, and in the late 1990s, when patents were strong and the number of patents was growing dramatically. R\&D expenditure leveled off in the early 1990s, when patents were getting stronger and the number of patents was growing, and again in the early 2000s, when patents were strong and the number of patents was growing."); But see Cassandra Mehlig Sweet and Dalibor Sacha Eterovic Maggio, 'Do Stronger Intellectual Property Rights Increase Innovation?' (2015) 66 World Development 665, 667 (cautioning that statistics on R\&D are weak predictors of real innovative advances). ${ }^{5}$ Bronwyn $\mathrm{H}$ Hall and Rosemarie Ham Ziedonis, 'The patent paradox revisited: an empirical study of patenting in the U.S. semiconductor industry, 1979-1995' (2001) 32 RAND Journal of Economics 101, 102. ${ }^{6}$ Lemley (n 4), at 33-34 (,The increase in patenting doesn't seem to have any effect on economic growth. Nor does economic growth seem to explain the increase in patenting.").

7 Zvi Griliches, 'Patent Statistics as Economic Indicators: A Survey' (1990) 28 Journal of Economic Literature 1661, 1669; Bronwyn H Hall and Dietmar Harhoff, 'Recent Research on the Economics of Patents' (2012) NBER Working Paper 17773 <http://www.nber.org/papers/w17773> accessed 21 August 2020, at 35.

${ }^{8}$ Edwin Mansfield, 'Patents and innovation: An empirical study' (1986) 32(2) Management Science 173, 173-81; Wesley M Cohen, Richard R Nelson and John P Walsh, 'Protecting their Intellectual Assets: Appropriability conditions and why U.S. manufacturing firms patent (or not)' (2000) NBER Working Paper 7552 <https://www.nber.org/papers/w7552> accessed 21 August 2020; Hall and Ziedonis (n 5), 102 with further references; Roberto Fontanaa and others, 'Reassessing patent propensity: Evidence from a dataset of R\&D awards, 1977-2004' (2013) 42 Research Policy 1780-92 with further references.

${ }_{9}^{9}$ Salvatore Torrisia and others, 'Used, blocking and sleeping patents: Empirical evidence from a large-scale inventor survey' (2016) 45 Research Policy 1374, 1384. 
patents valueless. ${ }^{10}$ The rate of patent litigation is even smaller. Only approximately 1 to $2 \%$ of U.S. patents are ever litigated. ${ }^{11}$

4 The ensuing question has been labeled the patent paradox: If the expected average value of most patents is low, even lower than average acquisition costs, then why are firms patenting so aggressively? ${ }^{12}$ What are the reasons for the strong and resilient propensity to patent? ${ }^{13}$

5 Economic and legal scholarship has identified a number of possible explanations for this puzzle: Hall et al. refer to changes in the enforcement of patent rights, to the cumulativeness of innovation and the increasing complexity of technology, to shifts in technological opportunity in some areas, to strategic patenting by large corporations and the rise of patent assertion entities (PAEs), to a lack of resources and misaligned incentives in patent offices, and to growth in trade of high-technology products, leading to an increase in the demand for patents worldwide. ${ }^{14}$ Clarisa Long and other scholars point out that patents are attractive beyond the exclusivity they provide in that they signal innovativeness and other competences. ${ }^{15}$ Jeremy Bock documents IP management strategies such as yearly application-filing targets of companies that may contribute to an increase in filings. ${ }^{16}$ The growth in the number of patent lawyers in the late $20^{\text {th }}$ century, which far outpaced the increase in R\&D expenditures, similarly supported the new

\footnotetext{
${ }^{10}$ Harald Degner and Jochen Streb, 'Foreign Patenting in Germany, 1877-1932' in Pierre-Yves Donzé and Shigehiro Nishimura (eds), Organizing Global Technology Flows: Institutions, Actors, and Processes (London: Routledge 2018), 17-38, 20-1 with further references.

${ }_{11}^{11}$ Hall and Harhoff ( $\left.\mathrm{n} 7\right)$, at 28.

${ }^{12}$ Hall and Ziedonis (n 5), at 102; Gideon Parchomovsky and R Polk Wagner, 'Patent Portfolios' (2015) 154 U Pa L Rev 1, 5, 17 (summarizing the patent paradox); Sabrina Safrin, 'Chain Reaction: How Property Begets Property' (2007) 82 Notre Dame L Rev 1917, 1941-42; Lemley (n 4), at 42.

${ }^{13}$ Nancy Gallini, 'Do patents work? Thickets, trolls and antibiotic resistance' (2017) 50(4) Canadian Journal of Economics/Revue canadienne d'economique 893, 898.

${ }^{14}$ Hall and others (n 3), at 3.

${ }_{15}$ Clarisa Long, 'Patent Signals' (2002) 69 U Chi L Rev 625; Christine Godt, Eigentum an Information (Tübingen: Mohr Siebeck 2007), 262; Clark D Asay, 'The Informational Value of Patents' (2016) 31 Berkeley Tech LJ 259; Jason Rantanen and Sarah E Jack, 'Patents As Credentials' (2019) 76 Wash \& Lee L Rev 311 ("purposes beyond the strictly exclusionary"). See also Lemley (n 4), at 40-42 with further references. ${ }^{16}$ Jeremy W Bock, 'Patent Quantity' (2016) 38 U Haw L Rev 287, 310.
} 
"culture" of patenting throughout the global knowledge economy. ${ }^{17}$ Legal changes, in contrast, seem to have no or very little influence on the practice of patent filings and patent litigation. ${ }^{18}$ Mark Lemley concludes that "patent institutions seem to have taken on a life of their own, one largely beyond the reach of the policy levers we employ to try to calibrate innovation incentives". ${ }^{19}$

6 This somewhat frustrating conclusion forms the starting point of this paper. I do not question the validity of any of the explanations of the patent paradox that have been put forward in the literature. Instead, my aim is to explicate the structural interrelatedness of the various drivers of patenting races. To meet this end, the theory need not be elaborated from scratch. Suffice it to apply a well-established theory that makes plausible a very similar economic phenomenon, namely a demand and willingness to pay for certain products that exceeds their inherent ('autarky') value. This theory is the theory of network effects (NE theory).

7 In a nutshell, this paper claims that each national or regional patent system ${ }^{20}$ resembles a telephone network or a social media platform. Patents are perceived as nodes in a virtual network that, as a whole, exhibits network effects. The more patents there are, the more valuable it is to also seek patents. At the same time, the value of an existing patent increases with every additional patent within and even beyond the product and technology market concerned. Since patents thus display increasing returns to adoption, the willingness to pay for the next patent slopes upwards. A patent is a network product to which the fundamental law of demand does not apply. Not surprisingly therefore, the patent systems of many countries have passed through the same cycle of events that can

\footnotetext{
17 John H Barton, 'Reforming the Patent System' (2000) 287 Sci 1933; Dan L Burk, 'On the Sociology of Patenting' (2016) 101 Minn L Rev 421, 442 ("holding patents demonstrates its adoption of the proper role in the proper social script").

${ }^{18}$ Lemley (n 4).

$19 \mathrm{lbid}$, at 51.

${ }^{20}$ Patents filed or granted for a certain national or regional patent jurisdiction are independent of patents obtained for the same invention in other countries (cf. Art. 4bis(1) Paris Convention). The numerous formally independent patent laws share, however, the basic legal features responsible for the network effect discussed in this article. For reasons of simplicity, I therefore refer to "the" patent system/network in the singular. The interrelatedness of national/regional patent systems and the ensuing structure of indeed "the" global patent system are beyond the scope of this article.
} 
be observed in conventional network markets, e.g. for communication technologies. After a phase of early instability and a certain tipping point, they expanded quickly and eventually became "locked-in".

8 A modest body of legal scholarship draws upon NE theory to explain the proliferation of certain standard contract terms, corporate and other laws and the resilience of international organizations. ${ }^{21}$ Economic and legal studies concerned with patent law also speak of "patent networks" and point to self-reinforcing feedback mechanisms. ${ }^{22}$ But to my knowledge, the concepts of NE theory have not been systematically applied to patent law and the patent paradox. ${ }^{23}$ Closest to the arguments presented here are the "patent portfolio theory", according to which the value of a patent portfolio depends on the addition of new inventions, rather than persistent investments devoted to increasing the value of

${ }^{21}$ Clayton P Gillette, 'Lock-in Effects in Law and Norms' (1998) 78 BU L Rev 813, 817; Michael Klausner, 'Corporations, Corporate Law, and Networks of Contracts' (1995) 81 Va L Rev 757, 761-2; critical Larry E Ribstein and Bruce H Kobayashi, 'Choice of Form and Network Externalities' (2001) 43 Wm \& Mary L Rev 79, $108 \mathrm{ff}$. See further C Y Cyrus Chu, 'Precedent Externality, Network Effect, and the Possible Inefficiency of the Evolution of Laws' (2003) 16 European Journal of Law and Economics 187 (concerning the efficiency of tort rules); Dan L Burk, 'Law as Network Standard' (2005-2006) Yale Journal of Law \& Technology 63 (harmonization of Internet-related laws); Bryan Druzin, 'Buying Commercial Law: Choice of Law, Choice of Forum, and Network Externalities' (2009) 18 Tul J Int'l \& Comp L 131, 134-5; Bryan Druzin, 'Using Network Effects to strengthen International Institutions in a Time of Global Instability' (European Society of International Law Conferences Paper No 3, 2018); Andrea K Bjorklund and Bryan H Druzin, 'Institutional Lock-in Within the Field of Investment Arbitration' (2018) 39 U Pa J Int'I L 707.

${ }^{22}$ Economics: Shapiro (n 3), at 121 (companies are "increasingly inclined to seek patents, causing an increase in the propensity to patent, as well as an increase in the practice of defensive patenting"); Hall and others (n 3), at 3 (on strategic patenting with feedback mechanisms); Entezarkheir (n 4), at 603 ("Thus, patent thickets have triggered patenting on marginal innovations to enlarge patent portfolios for bargaining power in patent disputes."); Georg v Graevenitz, Stefan Wagner and Dietmar Harhoff, 'How to measure patent thickets-A novel approach' (2011) 111 Economic Letters 6, 7 ("Patent data may be thought of as network data, although it is not often analysed this way by economists.").

Legal scholarship: Paul A David, 'Intellectual property institutions and the panda's thumb: patents, copyrights, and trade secrets in economic theory and history' in Mitchel B Wallerstein, Mary E Mogee and Robin A Schoen (eds), Global Dimensions of Intellectual Property Protection in Science and Technology (Washington: National Academy Press 1993), 19, at $43-4$ (brief reference to network theory); R Polk Wagner, Understanding Patent-Quality Mechanisms (2009) 157 U Pa L Rev 2135, 2155 (observing that "even if most firms would be better off with high-quality patents (and fewer of them), adopting such a strategy in the face of others' more numerous (and lower quality) patents is disadvantageous"); Barnett (n 3), at $20 \mathrm{ff}$.; Bock (n 16), at 313 ("the decision to engage in high-volume patenting is likely a self-reinforcing practice"). See also European Patent Office, Scenarios for the Future (2007), 10 ("patent engine").

${ }^{23}$ This is a different research question than studying the significance of IPRs in network markets. See, in this regard, e.g. Mark A Lemley and David McGowan, 'Legal Implications of Network Economic Effects' (1998) 86 Calif L Rev 479, 523-41; Peter S Menell, 'Economic Analysis of Network Effects and Intellectual Property' in Ben Depoorter and Peter S Menell (eds), Research Handbook on the Economics of Intellectual Property Law (Cheltenham: Edward Elgar Publishing 2019), vol I. Theory. 
one particular invention, ${ }^{24}$ and the "chain reaction theory" of Sabrina Safrin, which suggests that the establishment and expansion of intellectual and other property rights have an internally generative dynamic. ${ }^{25}$ Yet none of these approaches uses the explanatory power of NE theory to tackle the patent paradox puzzle.

9 The article is structured as follows. The next section outlines core concepts of NE theory. Main section 3 conceptualizes patents as network products and the patent system as a virtual network that displays network effects. The concluding section summarizes the findings and briefly addresses their normative implications. In particular, it raises the question what kind of regulatory measure appears suitable to effectively address the high transaction costs and anticommons effects of the patent system.

\section{The Theory of Network Effects}

10 For a long time, economists assumed "that the consumption behavior of any individual is independent of the consumption of others". ${ }^{26}$ Under this condition, the shape of the demand curve is primarily affected by existing and expected supply, in particular the price of a good. That there are situations in which demand-side coordination greatly influences the willingness to pay for the next unit only became a topic with the rise of communications technologies after World War II. ${ }^{27}$ Due to the Internet and digitization, such network effects are now "rapidly diffusing across the economic landscape", from consumer and industrial products (Internet of Things) to energy (smartgrid, autonomous driving, renewable energy), bioinformatics, social media, advertising, content creation, and science (database development). ${ }^{28}$

\footnotetext{
${ }^{24}$ Alfonso Gambardella, Dietmar Harhoff and Bart Verspagen, 'The economic value of patent portfolios' (2017) 26 J Econ Manage Strat 735, 751.

${ }^{25}$ Safrin (n 12), at 184.

${ }^{26}$ Harvey Leibenstein, 'Bandwagon, Snob, and Veblen Effects in the Theory of Consumers' Demand' (1950) 64 The Quarterly Journal of Economics 183, 184.

27 Jeffrey Rohlfs, 'A Theory of Interdependent Demand for a Communications Service' (1974) 5 The Bell Journal of Economics and Management Science 16; Michael L Katz and Carl Shapiro, 'Network Externalities, Competition, and Compatibility' (1985) 75 The American Economic Review 424; Oz Shy, 'A Short Survey of Network Economics' (2011) 38 Review of Industrial Organization 119.

${ }^{28}$ Menell (n 23), at 4, 70; Carl Shapiro and Hal R Varian, Information Rules: A Strategic Guide to the Network Economy (Boston, MA: Harvard Business School Press 1999).
} 
11 According to Nicholas Economides, a network effect is present when the value to a buyer of an extra unit is higher when more units are sold, or, in other words, if the "value of good $X$ increases as more of the complementary good $Y$ is sold, and vice versa". ${ }^{29}$ Classic examples are telephone networks and nowadays online platforms like Facebook. The benefits of being part of such a network increases with the number of adopters, simply because with each new subscriber, everyone benefits from gaining a new potential communication partner. ${ }^{30}$ Similarly, but more indirectly, the more consumers adopt a certain operating system (say Android vs. Apple's iOS), the more applications will be produced for that system, resulting in increasing returns to adoption for all consumers. ${ }^{31}$ Increasing returns then trigger positive feedback processes within the network and, as the other side of the coin, raise the costs of switching to an alternative network. ${ }^{32}$

12 Formally, such networks are composed of links that connect nodes. ${ }^{33}$ The nodes in our examples are the telephone extensions, the Facebook accounts, and the software installations. These individual goods form a network and are properly called network products only, however, if there are links between the nodes. In the case of communication networks, such connections are evidently present. But what about the software example? What kind of connection is there between computer programs on separate, unconnected hardware?

\footnotetext{
${ }^{29}$ Nicholas Economides, 'Competition policy in network industries: an introduction' in Dennis W Jansen (ed), The New Economy and Beyond. Past, Present and Future (Cheltenham: Edward Elgar Publishing 2006) 96, 98; Nicholas Economides, 'The Economics of networks' (1996) 14 International Journal of Industrial Organization 673, 680; See further Stan J Liebowitz and Stephen E Margolis, 'Network Externality: An Uncommon Tragedy' (1994) 8 Journal of Economic Perspectives 133, 135 (the net value of an action (consuming a good, subscribing to telephone service) is affected by the number of agents taking equivalent actions); 'Network Externalities (Effects)', Palgrave Dictionary of Economics (London: Palgrave Macmillan 1998) (a change in the benefit, or surplus, that an agent derives from a good when the number of other agents consuming the same kind of good changes); Jeffrey Church, Neil Gandal and David Krause, 'Indirect network effects and adoption externalities' (2008) 7(3) Review of Network Economics 337, 337 (,network effect exists if consumption benefits depend positively on the total number of consumers who purchase compatible products ").

${ }^{30}$ Menell (n 23), at 9.

${ }^{31}$ Michael L Katz and Carl Shapiro, 'Technology Adoption in the Presence of Network Externalities' (1986) 94 Journal of Political Economy 822, 822-3 (VHS vs. beta); W Brian Arthur, 'Competing Technologies, Increasing Returns, and Lock-In by Historical Events' (1989) 99 The Economic Journal 116.

${ }^{32}$ Paul Pierson, 'Increasing Returns, Path Dependence, and the Study of Politics' (2000) 94 The American Political Science Review 251, 252.

${ }^{33}$ Economides (n 29), at 674; Economides (n 29), at 98.
} 
13 The key concept in answering this question is complementarity. ${ }^{34}$ Goods and services are complementary network products if it is beneficial to use them together, if they form components of a whole, which is only complete and achieves its full value if the maximum number of nodes are connected. ${ }^{35}$ The opposite of the component is the substitute, for example a competing telephone network, a competing social media service or alternative software. ${ }^{36}$ In contrast, several extensions and accounts within one telephone network or social media platform mutually supply each other. Indeed, without at least two extensions/accounts, the respective services are useless altogether. Their inherent, autarkic value is zero. Their entire use value consists in forming part of a communication network over which adopters are able to interact with other users. This "synchronization value" is the essence of network effects. ${ }^{37}$

14 But not always is the complementarity of network products so direct and strong. Instead, there is a continuum between various stages of complementarity and the strength of resulting network effects. ${ }^{38}$ For many products, consumers' utility functions are completely or mainly independent. The use value of these products is inherent in the commodity. Menell gives the example of ice cream: "My enjoyment of a particular flavor ... does not depend significantly on the utility that other consumers derive from the purchase and consumption of ice cream." ${ }^{39}$ Scoops of ice cream do not compose a network because their use value is autarkic. Social media accounts, in contrast, derive their entire value from being connected to the network and thereby to other users.

15 Somewhere between communication services and foodstuffs rank the many goods and services that exhibit both autarkic and synchronization value. The example on point here

\footnotetext{
${ }^{34}$ Economides (n 29), at 679.

${ }^{35}$ Lemley and McGowan (n 23), at 483 fn 8; Church, Gandal and Krause (n 29), at 340 ("Consumer demand is for a group of complementary products that, when combined or consumed together, provide value.").

${ }^{36}$ Ohio et al v American Express Co et al 585 U S__ (2018) (Breyer, J., dissenting).

37 'Network Externalities (Effects)' (n 29); Katz and Shapiro (n 27); Economides (n 29), at 96, 100; 'Network Goods (Theory)', The New Palgrave Dictionary of Economics (London: 2nd edition, Palgrave Macmillan 2008); Lemley and McGowan (n 23), at 488-9.

${ }^{38}$ Lemley and McGowan ( $\mathrm{n} 23$ ), at 488, 591; Ohio et al v American Express Co et al $585 \mathrm{U} S$ (2018) (comparing network effects between merchant-Visa and Visa-Credit-card-holder vs. reader-newspaper and newspaper-advertiser).

${ }^{39}$ Menell (n 23), at 6.
} 
is the operating system of a computer. It is independently/inherently valuable because one can use it to manage one's hardware. But it also exhibits 'indirect' or 'virtual' network effects in that complementary products on a related market - e.g. software applications for smartphones - will be more readily available as the number of users of an operating system increases..$^{40}$ As a consequence, demand for the operating system depends significantly on the availability of complementary applications, and vice versa. Indirect network effects are not limited to the digital realm or the Internet of Things, though. Offline examples include the demand for certain cars and the availability of and demand for complementary repair and fueling or charging facilities. ${ }^{41}$ In sum, the strength and effects of complementarities are strongest in the case of real physical communication networks. They attenuate the more indirect the complementarity/connection between the network products and the more important their autarky value is.

16 Apart from these variations, network markets typically display the following features: If a new network product such as a new social media service is launched, a phase of instability follows, during which several suppliers might compete for the market, with a contingent outcome. ${ }^{42}$ At a certain tipping point, however, one of the competing networks expands very rapidly. Due to the positive feedback loop of ever more users adopting a network and thereby increasing the value of the next account, the pace of market penetration is much faster in network markets than in non-network markets. ${ }^{43}$ Not only is growth quick but, at least for direct network products such as social media applications, the fundamental law of demand is violated because "for some portions of the demand curve, as sales expand, people are willing to pay more for the last unit". ${ }^{44}$ The reason for this phenomenon is that joining the dominant network becomes ever more valuable if not unavoidable over time, even if a substitute with superior qualities is on offer for a lower

\footnotetext{
${ }^{40}$ Katz and Shapiro (n 27); Michael L Katz and Carl Shapiro, 'Systems Competition and Network Effects' (1994) 8 Journal of Economic Perspectives 93, 97-100; Economides (n 29), at 100; Liebowitz and Margolis, (n 29), at 133, 136; Lemley and McGowan (n 23), at 491-4; Menell (n 23), at 7.

${ }^{41}$ Pierson (n 32), at 251, 254 (Increased use of a technology encourages investments in the linked infrastructure, which in turn attracts still more users to the technology).

${ }^{42}$ Katz and Shapiro (n 31); Economides (n 29), at 108 (competition for, not in the market); 'Network Goods (Theory)' (n 37); See also James Mahoney, 'Path dependence in historical sociology' (2000) 29 Theory and Society 507, 513 (critical juncture); Pierson (n 32), at 263.

${ }^{43}$ Economides ( $n$ 29), at 104; Menell (n 23), at 7.

${ }^{44}$ Economides (n 29), at 100-1.
} 
price. If production costs are falling, constant, or nonexistent, this positive feedback loop tends to crowd out competing incompatible networks and result in natural monopoly. 45 But even in the case of positive production costs, network markets regularly result in 'winner take most' distributions because a "firm with a large market share has more complementary goods and therefore its good is more valuable to consumers." 46

17 These basic tenets of NE theory have achieved paradigmatic status in economics and have furthermore influenced other social sciences, often under the rubric of "path dependencies". ${ }^{47}$ However, neither theoretical models nor the rare empirical case studies ${ }^{48}$ show that or under which conditions network effects lead to efficient outcomes. Whether the best or an inferior technology or product prevails depends on the circumstances and ultimately on the criteria for evaluating the outcome. ${ }^{49}$ It is therefore unclear and hotly debated whether network markets raise specific regulatory concerns and which, if any, intervention is called for. ${ }^{50}$

\footnotetext{
${ }^{45}$ Liebowitz and Margolis (n 29), at 143; Lemley and McGowan (n 23), at 484 (pointing out the differences between natural monopolies as supply-side effects and network effects as a demand-side phenomenon). ${ }^{46}$ Katz and Shapiro (n 40), at 111 (strong winners and strong losers); Economides (n 29), at 104.

47 See Douglas C North, Institutions, Institutional Change and Economic Performance (Cambridge: Cambridge University Press 1990), 95 (defining path dependencies as institutional patterns or event chains that have deterministic properties); Paul A David, 'Why are institutions the 'carriers of history'?: Path dependence and the evolution of conventions, organizations and institutions' (1994) 5(2) Structural Change and Economic Dynamics 205, 208; Gillette (n 21), at 817 ("The problem of path dependence and lock-in arises when a technological standard that has obtained a foothold, based on fortuity or favorable conditions that no longer apply, possesses certain characteristics that inhibit displacement by demonstrably superior technologies"); Mahoney (n 42), at 507; Pierson (n 32), at 251.

${ }^{48} \mathrm{Cf}$. 'Network Goods (Empirical Studies)' (n 37), with further references (can one supplier ask a premium for substitutable, more or less identical products?).

${ }^{49}$ See, on the one hand, Joseph Farrell and Garth Saloner, 'Standardization, Compatibility, and Innovation' (1985) 16(1) The RAND Journal of Economics 70, 81 (there can be inefficient inertia, or inefficient innovation, and these problems cannot be entirely resolved by communication among firms); Menell ( $\mathrm{n} 23$ ), at 6 ("Take, for example, a social network like Facebook. A new entrant to this market, say Google+, might offer enhanced functionality. But if most of my social network is already on Facebook and I cannot easily bridge the two networks, then I am far less likely to switch"). Contra Liebowitz and Margolis (n 29), at 4 ("Observable instances in which a dramatically inferior standard prevails are likely to be short-lived, imposed by authority, or fictional."); Katz and Shapiro (n 27), at 93, 108 ("there is no general theoretical result implying excess inertia in market equilibria").

${ }^{50}$ Tim Weitzel, Oliver Wendt and Falk V Westarp, 'Reconsidering Network Effect Theory' (2000), 91 ECIS $<$ http://aisel.aisnet.org/ecis2000/91> accessed 21 August 2020; Economides (n 29), at 96, 106-7 (large network effects pose an interesting dilemma for antitrust authorities).
} 


\section{The Patent System as a Virtual Network}

18 The following section applies these basic concepts of NE theory to the patent system. The underlying hypothesis is that individual patents exhibit characteristics of network products that make up a virtual network - commonly called the "patent system". The claim accordingly is that the value of an existing patent increases automatically if patents are granted to others. Conversely, the more patents there are, the more valuable it is to also seek patents. Such a demand-side effect presupposes, however, a complementarity between individual patents. Patents must, in other words, supplement each other in ways similar to telephone network extensions and other indirect network products. If it cannot be specified and demonstrated precisely how patents complement each other to form a whole - the patent "system" - the application of NE theory to explain the patent paradox would suffer from unsubstantiated concept stretching. ${ }^{51}$

\subsection{Legal Independence and Autarky Value of Patents}

19 From a strictly legal point of view, patents are indeed more akin to non-network commodities such as ice cream that are demanded and consumed independently of other goods. A patent is a private, exclusive right in a new technology that must be capable of industrial application in and of itself. ${ }^{52}$ That property right can be exercised separately by each patent holder. One patented technology might be implemented in a product, another one licensed, a third one remain unused altogether, etc. It is the very essence of a

\footnotetext{
${ }^{51}$ This accusation has been directed at the use of NE theory to explain the proliferation of certain standard contract forms and corporations. Cf. Klausner (n 21), at 774 ("Unlike a telephone network, where units are physically connected, a contractual network (like a PC network) is linked together by commonly used complementary products."); Druzin (n 21), at 159-60 ("...commercial law is more analogous to a telephone than a Ferrari."). Critical Pierson (n 32), at 252; see also Lemley and McGowan (n 23), at 483 ("Significant confusion remains as to what constitutes a 'network effect,' and how such effects should be used in the law."), at 570-6 (critically examining Klausner's assumption about network effects in contract and corporation law practice); Ribstein and Kobayashi (n 21), at 109-16.

${ }^{52}$ Preamble, Art. 27(1) TRIPS.
} 
property right to confer these powers to each right holder individually, who may exercise her right at will, irrespective of the behavior of other patent applicants/holders. ${ }^{53}$

20 From an economic perspective, too, patents generate private value if there are no other patents in the product or technology market or even no patents at all. ${ }^{54}$ They possess, in other words, an inherent use value for the owner that explains the demand for patents at least in part. ${ }^{55}$ The essence of this autarky value is the exclusivity that patent holders enjoy, which can result in supracompetitive prices and large private returns. ${ }^{56}$

21 The expectation of additional profits must logically have been the main motivation for those who lobbied for the introduction of national and international patent protection in the $19^{\text {th }}$ century, such as Werner von Siemens and export-oriented U.S. corporations on the occasion of the Vienna World Exhibition in $1873 .{ }^{57}$ The prospect of these benefits also explains why the introduction or strengthening of patents correlates with an increase in patenting and also in the use of patents as a tool of firm strategy. ${ }^{58}$ In their famous empirical study of patenting in the U.S. semiconductor industry between 1979 and 1995, Hall and Ziedonis furthermore found that the strengthening of U.S. patent law in the early 1980s attracted specialized IP firms whose business model was to develop technologies and then license the respective patents to commodity firms manufacturing chips. ${ }^{59}$ For these upstream licensors, patents are absolutely crucial, not only in order to attract

\footnotetext{
${ }^{53}$ Christoph Menke, Kritik der Rechte (Berlin: Suhrkamp 2015).

54 'Network Externalities (Effects)' (n 29) ("autarky value[...] is the value generated by the product even if there are no other users").

${ }^{55}$ See also Ribstein and Kobayashi (n 21), at $108 \mathrm{ff}$. (providing evidence that the inherent characteristics of two business forms, rather than network externalities, drive the choice of the forms).

${ }^{56}$ Hall and Harhoff (n 7), at 35; Gambardella, Harhoff and Verspagen (n 24), at 751 ("wide portfolios also arise for more genuine reasons associated with the opportunity to increase the economic value of inventions").

57 See Stephen Pericles Ladas, Patents, trademarks, and related rights: national and international protection (Cambridge, MA: Harvard University Press 1975), vol 1, 61-7; Peter Kurz, Weltgeschichte des Erfindungsschutzes (Köln: Carl Heymanns Verlag 2000), 361-8.

${ }^{58} \mathrm{Hall}$ and Harhoff (n 7), at 14, 24 (given software patentability, ICT firms engaged in patent portfolio races needed to add software patents to their portfolio); Hall and Ziedonis ( $n$ 5), at 101-28; lan M Cockburn and Megan MacGarvie, 'Patents, Thickets, and the Financing of Early-Stage Firms: Evidence from the Software Industry' (2007) NBER Working Paper 13644 <http://www.nber.org/papers/w13644> accessed 21 August 2020, at 2; Jell, Henkel and Wallin (n 4), at 533-4.

${ }^{59}$ Hall and Ziedonis (n 5), at 107.
} 
venture capital but first and foremost to monetize their output. ${ }^{60}$ Correspondingly, they tend to show a higher propensity to patent than downstream commodity firms. ${ }^{61}$

22 Yet the latter, integrated firms have also joined the patenting race. ${ }^{62}$ In their case, successful first movers in the enforcement of patents seem to have established a new model of competitive strategy, which was quickly imitated by others. For example, Polaroid's successful patent infringement suit against Kodak in 1986, in which Polaroid was awarded almost $\$ 1$ billion in damages and Kodak was effectively precluded from competing in the instant camera market, made executives in other large manufacturing companies aware of the great potential of patents. ${ }^{63}$ Similarly, the first filing of patents on gene fragments in 1991 is said to have caused a "frenzy to obtain patent rights over genetic fragments" across the biotechnology sector. ${ }^{64}$

\subsection{Complementarity and Synchronization Value of Patents}

23 These observations already illustrate that the propensity to patent cannot be explained on the basis of an isolated interest of individual patentees in privatizing technologies alone. Instead, because patents are complementary to other patents, they possess an additional synchronization value that makes it attractive to seek patents irrespective of their individual autarky value.

\footnotetext{
${ }^{60}$ Gallini (n 13), at 908.

${ }^{61}$ Hall and Ziedonis (n 5), at 116; Barnett (n 3), at 34-5 (distinguishing between upstream licensors with strong R\&D and patents such as Qualcomm and downstream manufacturers and other intermediate users with lower R\&D intensity). But see Bronwyn $\mathrm{H}$ Hall, 'Is there a role for patents in the financing of new innovative firms?' (2019) 28 Industrial and Corporate Change 675 <https://papers.ssrn.com/sol3/papers.cfm?abstract_id=3177027> accessed 21 August 2020, at 6 ("With the exception of the Israeli firms studied by Greenberg (2013) and Conti et al. (2013), in no case do more than half the firms have at least one patent application during the period of study.").

${ }^{62}$ On the differences between patent and patent portfolio/arms races see Jell, Henkel and Wallin (n 4), at 531 fn. 1.

${ }^{63}$ Hall and Ziedonis (n 5), at 109 (''demonstration effect' of Polaroid's successful patent infringement suit against Kodak"). See also Hall and others (n 3), at 22-4 with further references; Jell, Henkel and Wallin (n 4), at 531-549.

${ }^{64}$ Safrin (n 12), at 1943-44.
} 


\subsubsection{Patents of Competitors}

24 This interrelatedness of patents follows firstly from the fact that patentees do not operate in a vacuum but under (more or less) competitive conditions. IP management decisions are always affected by commercial practices of other market participants. This holds true for all patents, irrespective of whether they concern discrete or complex technologies. ${ }^{65}$ In other words, competition links individual patents together.

25 But why and how precisely does the "basic nature of trade" 66 support the formation of a virtual patent network? As illustrated, first movers introduce patents as a business strategy ${ }^{67}$ They acquire and enforce patents in order to realize supracompetitive prices for innovative products or technologies. Profitable test cases are expanded into a systematic IP management and patenting strategy. The ensuing patent portfolio has an additional value of its own, which exceeds the sum of its parts. Patent portfolios function as effective barriers to entry vis-à-vis new market participants. ${ }^{68}$ Firms possessing substantial patent portfolios furthermore manage to invest more in R\&D than small and upstart companies, which allows them to retain and expand their already existing market power. ${ }^{69}$ Finally, the larger the patent arsenal, the less likely is it that individual parts of it will be challenged in opposition proceedings. ${ }^{70}$

26 Theoretically, competitors could counter such patenting strategies by revealing their inventions without filing for a patent. Such a public domain strategy may be beneficial

\footnotetext{
${ }^{65}$ Markus Reitzig, 'The Private Values of 'Thickets' and 'Fences': Towards an Updated Picture of the Use of Patents across Industries' (2004) 13 Economics of Innovation and New Technology 457, 457-76. On additional network effects of patents in complex technologies see infra 3.2.2.

${ }^{66} \mathrm{Cf}$. Druzin (n 21), at 136 (the "basic nature of trade" triggers network effects).

${ }^{67}$ Jell, Henkel and Wallin (n 4), at 542 (initiators of offensive patent races).

68 Torrisia and others (n 9), at 1380 (large firms exhibit a larger share of strategic non-use (30\%) and sleeping patents (14\%: patent applications filed for reasons different from commercial use and blocking other parties) than small and medium-sized enterprises).

${ }^{69}$ Gregory R Day and W Michael Schuster, 'Patent Inequality' (2019) 71 Ala L Rev 115, 150 ("dominant firms seem to be using large portfolios to insulate their market power from some of the most innovative firms").

${ }^{70}$ Dietmar Harhoff, Georg v Graevenitz and Stefan Wagner, 'Conflict Resolution, Public Goods, and Patent Thickets' (2016) 62(3) Management Science 704, 715.
} 
under certain circumstances, ${ }^{71}$ but in general, the autarky value of patents and patent portfolios is far too attractive to be foregone. Yet the decision to enter into a patent portfolio race is not merely an instance of mimicking a successful business strategy to internalize innovation returns.

27 Rather, the impression that "if your competitors have them, you need them too"72 indicates an additional, systemic "logic of patent portfolio races". ${ }^{73}$ The more patents first movers amass, the more important it becomes for their competitors to adopt the same IP management strategy, for a number of reasons: ${ }^{74}$ Acquiring patents in each and every patentable technology firstly guarantees a minimum of freedom to operate. Secondly, holding many patents increases bargaining power in potential patent disputes. Either the threat of retaliation discourages competitors to allege patent infringement in the first place or patents can be used as counter-weapons or bargaining chips in settlement negotiations, which might lead to cross-licensing agreements that further strengthen the combined market power of the parties involved. In such situations, quantity matters: "the larger your sack of coal, the more chance there is that there's a diamond in there. And, even if there isn't, the probability that there might be, makes the negotiation more likely to go your way". ${ }^{75}$

28 These effects are positively associated with the degree of competition and the lack of technological opportunities. That is to say, the more intense competition is and the fewer technological alternatives are available, the more vital it is to participate in the patent arms

\footnotetext{
${ }^{71}$ A famous but rare example is the "Statement Concerning CERN W3 Software Release Into Public Domain" of 30 April 1993, <https://cds.cern.ch/record/1164399? In=de\#> accessed 21 August 2020.

${ }^{72}$ Hall and Harhoff (n 7), at 35.

${ }^{73}$ Harhoff, Graevenitz and Wagner (n 70), at 719. The significance of strategic patententing is noted both by critical observers of the patent system (see Peter Drahos and John Braithwaite, Information Feudalism. Who Owns the Knowledge Economy (London: Earthscan 2002), 46) and pro-patent lobbying organisations (see <https://www.4ipcouncil.com/4-SMEs/4-reasons-patent> accessed 21 August 2020 (market access, negotiating, funding and strategic value as the four "key benefits to patenting“)).

${ }^{74}$ Cf. Hall and Ziedonis ( $n$ 5), at 107; Shapiro (n 3), at 129-30 (cross licenses the norm in markets for microprocessors); Drahos and Braithwaite (n 73), at 45; Safrin (n 12), at 1944-45; Ralph Siebert and Georg $v$ Graevenitz, 'Jostling for advantage or not: Choosing between patent portfolio races and ex ante licensing' (2010) 73 Journal of Economic Behavior \& Organization 73, 226, with further references; Entezarkheir (n 4), at 603.

${ }^{75}$ European Patent Office (n 22), at 37.
} 
race in order to avoid being forced to exit the market. ${ }^{76}$ The emergence of PAEs seems to have further amplified this logic. Since these actors increase the likelihood that technology and commodity companies will be confronted with a patent infringement claim, the interest in being adequately protected by large patent portfolios becomes more important, too. ${ }^{77}$

29 The theory of network effects provides a plausible theoretical framework for these observations. Although patents in theory and, as the case may be, also in practice protect free-standing new technologies that are independently susceptible of industrial application and thus commercial value, they complement each other. This complementarity does not follow from the fact that it is beneficial to use the technologies involved together. Rather, complementarity vests in the patent exclusivity that each competitor enjoys vis-à-vis other competitors. Patents on a particular product or technology market result in a network of reciprocal, legal-economic relationships between all patent holders involved. Every one of them is in a position to either authorize or prohibit the use of a technology. Every patent a firm adds to its portfolio increases the likelihood that its competitors will encounter difficulties in their operations. Accordingly, the value of the patents already held by these competitors as defensive tools for counter-strikes or cross-licensing negotiations increases when another firm acquires a patent. Conversely, the thicker the web of patents on a market, the more valuable is the next patent unit for each competitor to be used for offensive or defensive purposes. These benefits are independent of the inherent autarky value of the respective technology and the exclusivity therein. They ultimately consist in the possibility to participate in the patent game or, in more formal terms, in the synchronization of veto rights.

30 In sum, at a certain level of patent proliferation on a market (tipping-point), patents result in increasing returns to adoption for all competitors, which leads to an increase in demand for patents and further feedback and lock-in effects. The expected synchronization

\footnotetext{
76 Torrisia and others (n 9), at 1382 (documenting a positive association between defensive or offensive blocking motives and intensity of competition); Graevenitz, Wagner and Harhoff (n 2), at 559 (finding that the patent explosion coincides with the decrease in technological opportunities after 1994).

${ }_{77}$ Gallini ( $n$ 13), at 911 ("trolls contribute to the thicket's density in forcing targeted firms to accumulate more patents in defense"); Hall (n 61), at 12; Comino, Manenti and Thumm (n 2), at 415-7.
} 
benefits from joining this patent network are additional revenues from exclusive exploitation or licensing or, at a minimum, a guaranteed sphere of freedom to operate.

\subsubsection{The Role of the Patent Subject Matter: Complex and Discrete Technologies}

31 The complementarity of individual patents, their synchronization value and the resulting patent network effect is even stronger if not only patents supplement each other but also their subject matter, i.e. the technologies in question. In this case, two network effects intertwine: one on the legal level of patents and one on the underlying level of protected products and processes.

32 In economics, this phenomenon is discussed under the rubric of "complex technologies", which in turn is tightly tied to the issue of patent thickets. In his groundbreaking 2001 article, Carl Shapiro pointed out that patent thickets concern complements of a final product - his example was a graphics chip for use in personal computers or video consoles - that are subject to independent patents held by different right holders. ${ }^{78}$ Correspondingly, Shapiro distinguishes between "complementary patents", which should form part of a patent pool, and "substitute or rival patents", which should not. ${ }^{79}$ Later studies confirmed that patent thickets as well as patent pools occur more frequently in "complex" technology areas, where marketable products such as computers consist of many modular components, than in "discrete" technology areas, where a patent covers one separate technological opportunity or even a final product, for example a molecular formula for an active pharmaceutical ingredient. ${ }^{80}$

33 The correlation between complex technologies and patent thickets/pools calls for an explanation. Some commentators speak of a "natural" phenomenon. ${ }^{81}$ Von Graevenitz et

\footnotetext{
${ }^{78}$ Shapiro (n 3), at 122-4.

79 Shapiro (n 3), at 134.

${ }^{80}$ Graevenitz, Wagner and Harhoff (n 22), at 6-9; Graevenitz, Wagner and Harhoff (n 2), at 525 (optics as complex technology); Hall and others (n 3), at 20-1 (reviewing evidence that technology is getting more complex and interwoven); Barnett (n 3), at 15 (documenting patent pools in ICT markets); Olga Gurgula, 'Strategic accumulation of patents in the pharmaceutical industry and patent thickets in complex technologies - two different concepts sharing similar features' (2017), 48(4) IIC 2017, 385, 388 (complex industries as semiconductors, biotechnology, computer software, the Internet and nanotechnology).

${ }^{81}$ Gurgula (n 80), at 388; Comino, Manenti and Thumm (n 2), at 421.
} 
al. assert that if it is unlikely that any one firm holds all the patents necessary for the commercialization of a complex product, "this implies that the value of firms' patent portfolios depends on the size and composition of rival firms' portfolios", resulting in "strategic interdependencies". ${ }^{82}$ And Barnett points out that ICT markets demand patent pools and standards "because communications technologies are inherently network goods: that is, the value of the technology increases as a function of the number of users of that same technology". ${ }^{83}$

$34 \mathrm{NE}$ theory is again useful to elaborate on and specify these accounts. It firstly requires that one identify who demands what because of which kind of complementarity. Posing these questions reveals that von Graevenitz et al. and Barnett address different phenomena, namely the propensity of firms in complex technology areas to file for patents (von Graevenitz et al.) and their subsequent propensity to pool these patents (Barnett). The two scenarios concern different network products (patents vs. pooled patents) and different complementarities.

35 As explained in the preceding section, NE theory furthermore teaches that under conditions of intense patenting of at least one competitor on a technology or commodity market, filing for patents is attractive and at a certain level of patenting unavoidable for all other competitors because it preserves their freedom to operate, be it by working the technology or by using the patent as a defense weapon or bargaining chip. The respective network effect is present on all technology and commodity markets where patenting occurs.

36 However, the strength of this effect varies according to the degree to which the subject matter of the patents concerned, i.e. the technologies, can be used independently. That accessory aspect is where the distinction between complex and discrete technologies comes into play.

\footnotetext{
82 Graevenitz, Wagner and Harhoff (n 2), at 525.

${ }^{83}$ Barnett (n 3), at 6.
} 
37 Patents in discrete technologies exhibit autarky value because and in so far as each patent covers one separate technological opportunity or even final product (e.g. a drug). ${ }^{84}$ The stronger this autarky value, the relatively less significant and thus weak is their competitive synchronization value. Strategic concerns vis-à-vis competitors and their patent portfolios are important and in part explain the dense webs of patents observable in these markets, ${ }^{85}$ but they do not take center stage because the core freedom to operate has already been preserved.

38 In the case of patents in complex technology areas, the relative strength of autarky and synchronization values is reversed. A component that needs to be combined with other technologies in order to make up a functional end product has little autarky value. Unless a fully integrated firm manufactures all necessary components, a producer of a component has to coordinate with other firms in order to bring about the marketable commodity. Otherwise, the demand for the component will be zero. ${ }^{86}$ The autarky value of a patent in such a technology is equally small.

39 If one of the producers of a component acquires a patent, it makes sure that no other component supplier will take its place. If the patent concerns an essential component, the position is even stronger. On this exclusive basis, the holder of a patent in an (essential) component is in a position to demand a larger piece of the cake, i.e. the total revenues from the sale of the complex end product (e.g. a computer). Such a move affects all relevant component suppliers. Providers of substitute components are most directly affected. Yet firms producing other components on other markets also suffer because the negotiation position of these non-competitors in the necessary coordination process towards the end product deteriorates. Whereas the patent holder has secured a fraction of the total revenue if the respective technology is included in the complex technology (standard), non-patentees risk losing market shares because of price competition on the commodity market (if the technology is publicly known), and they even run the risk of

\footnotetext{
${ }^{84}$ Gurgula ( $\mathrm{n} 80$ ), at 388 (defining discrete technologies).

${ }^{85}$ Gurgula (n 80), at 392-396, 399-400.

${ }^{86} \mathrm{Cf}$. Shapiro (n 3), at 123 (referring to the classic complements problem).
} 
being excluded from the coordination process if another firm independently invents the technology and files for a patent first.

40 The interest in remaining part of the coordination process depends on the expected revenues from the sales of the envisaged end product. If that commodity is itself a network product that might become a market standard (such as an ICT standard), potential profits on these downstream winner-take-all markets can be very high. Accordingly, the synchronization value of a patent in a component included in such a network product is equally high, even if it only concerns a tiny fragment of the whole. The fundamental NE theorem thus applies: The value of component patent $X$ increases as more complementary patents are granted, and vice versa. ${ }^{87}$ Correspondingly intense are patent and patent portfolio races in complex technology areas such as ICT markets. ${ }^{88}$

41 The willingness to pool all these patents is also a consequence of a network effect. The boundaries of such a network are marked by the shared goal to bring about a marketable end product. A patent pool concluded to this end formalizes the already existing links between the complex technologies and patents involved. The value of participating in such a pool increases for each new component supplier as more other suppliers join, and vice versa, for the more comprehensive the combined whole is, the more valuable it and the shares in it are. Patent pools thus display increasing returns to adoption for component suppliers. Demand for the adoption of the pool as the network product tends to slope upwards. If the result of the pooling is itself a network product, e.g. a communication technology standard, network effects can be observed both on the upstream side among component suppliers as "users" of the standard, and on the downstream side among consumers who adopt it. ${ }^{89}$

\subsubsection{Complementarity Across Markets: Patents and Finance}

42 The complementarities and network effects discussed up to this point are relatively clearly defined. Their boundaries correspond to (1) the boundaries of a market on which

\footnotetext{
${ }^{87}$ Supra note 29.

${ }^{88} \mathrm{Cf}$. Harhoff, Graevenitz and Wagner (n 70), at 719.

${ }^{89} \mathrm{Cf}$. Barnett (n 3), at 6.
} 
competitors patent strategically or (2) the boundaries of a complex end product made up of patentable components. Yet the claim of this article is broader than that. It suggests that a country's patent system exhibits a network effect across all sectors of the respective economy, irrespective of the markets and technologies concerned.

43 At first sight, this hypothesis seems far-fetched. Even if it is true that companies react to the patenting activity of competitors and of suppliers of complementary products needed for assembling a complex end product, the patent management of, say, a pharmaceutical company intuitively appears to be completely unrelated to that of, e.g., an ICT company. Patents in pharmaceuticals simply do not complement patents in communications technologies.

44 It would, however, be premature to jump to this conclusion. The patents filed or granted for a jurisdiction do indeed complement each other and form a whole that, as a whole, accommodates a demand and thus possesses value beyond the exclusionary power of individual patents or patent portfolios and irrespective of the markets and technologies concerned. That complementarity and synchronization value concerns the use of patents as a security for lenders and generally as a quality signal for investors. ${ }^{90}$ Qualitative evidence demonstrates that many firms assume that patents can serve as a positive signal of lower risk and higher future profitability. ${ }^{91}$ The more patents they hold, the more they advertise their innovativeness by reference to this measure. ${ }^{92}$ Investors seem to respond to this signal. It was shown that companies that hold more patents and have more patent applications pending "are more likely to receive funding from outside investors, and more likely to subsequently 'exit' from the entrepreneurial phase through

\footnotetext{
${ }^{90}$ Hall and Harhoff (n 7), at 22 ("some firms still amass patents in order to signal quality in later stage financing or for cross licensing purposes."); Burk (n 17) ("venture capitalists look for patents as a marker of innovation because patents are what innovative firms are supposed to have"); Rantanen and Jack ( $n$ 15) ("purposes beyond the strictly exclusionary").

${ }^{91}$ Lehmann-Hasemeyer and Streb, 'The Berlin Stock Exchange in Imperial Germany: A Market for New Technology?' (2016) 106(11) American Economic Review, 3558, 3569.

${ }_{92}$ Lehmann-Hasemeyer and Streb (n 91), at 3560-1 ("Whereas only 25 percent of the firms with only one patent made this information public, three-quarters of the firms which patented more than ten innovations mentioned their patents at the time of their IPO ").
} 
IPO or acquisition". ${ }^{93}$ Taken together, patents aid firms to go public, and the capital market, in turn, helps "to finance innovation activities measured by patents". ${ }^{94}$ These links between patents and finance explain why the capital intensity of a firm has a more important effect on the propensity to patent than its $R \& D$ spending. ${ }^{95}$

45 More recently, patents and other IPRs have also been used by multinational enterprises (MNEs) with a statutory seat in high-tax countries in Europe and North America to minimize their corporate income tax. To this end, they transfer patents for a low price to a related corporation in a low-tax jurisdiction. Through intercompany arrangements, the MNE then allocates a large share of its profits to the low-tax entity, thereby significantly reducing its corporate income in high-tax countries. ${ }^{96}$ Against this background, it is not surprising that tax-motivated income shifting is positively associated with the degree of patent concentration. The more patents a company holds, the more likely is it that these patents will be used as part of a tax minimization strategy. ${ }^{97}$

46 The assetization and financialization of patents displays self-reinforcing tendencies. "The more people believe that an intellectual asset is valuable, the more its value increases, attracting the demand of other people in a self-reinforcing circle." $98 \mathrm{NE}$ theory is again

${ }^{93}$ Cockburn and MacGarvie (n 58), at 1422. See also Carolin Haeussler, Dietmar Harhoff and Elisabeth Mueller, 'How patenting informs VC investors - The case of biotechnology' (2014) 43 Research Policy 1286, 1293; Hall (n 61), at 5-8. But see Hoenig and Henkel, 'Quality signals? The role of patents, alliances, and team experience in venture capital financing' (2015) 44 Research Policy 1049, 1058 (venture capitalists value patents highly, but not as signals of the venture's technology quality).

${ }^{94}$ Lehmann-Hasemeyer and Streb ( $n$ 91), at 3567.

${ }_{95}$ Hall and Ziedonis (n 5), at 115, 118.

${ }^{96}$ Europe: Lisa Evers, Helen Miller and Christoph Spengel, 'Intellectual property box regimes: effective tax rates and tax policy considerations' (2015) 22 Int Tax Public Finance 502 <https://doi.org/10.1007/s10797014-9328-x> accessed 21 August 2020; Harald J Amberger and Benjamin Osswald, 'Patent Concentration, Asymmetric Information, and Tax-Motivated Income Shifting' (2020) WU International Taxation Research Paper Series No. 2020-05 <SSRN: https://ssrn.com/abstract=3600839 or http://dx.doi.org/10.2139/ssrn.3600839> accessed 21 August 2020, 1 (Apple is said to have achieved estimated tax savings of $\$ 14$ billion through IP shifting to Ireland). U.S.: Michael J Graetz and Rachael Doud, 'Technological Innovation, International Competition, and the Challenges of International Income Taxation' (2013) 113 Colum L Rev 347, 394; Andrew Blair-Stanek, 'Intellectual Property Law Solutions to Tax Avoidance' (2015) 62 UCLA L Rev 2, 5 ("IP-shifting strategies cost the Treasury as much as $\$ 90$ billion per year, a staggering one-third of the total U.S. income taxes paid by all corporations").

${ }_{97}$ Amberger and Osswald (n 96) ("patent concentration shapes an MNC's incentives to shift income via patents").

98 Ugo Pagano, 'The crisis of intellectual monopoly capitalism', (2014) 38 Cambridge Journal of Economics, 1409, 1423. 
helpful in explicating this demand-side effect. If it has been proven by first movers that patents can be successfully employed as collateral, as tax-minimization vehicles or generally as signals of innovativeness and competitiveness, others will imitate this strategy up to the tipping point, at which patenting becomes a very general "indication of participation in the expected social order". ${ }^{99}$

47 Under these conditions, the value of an extra patent is higher when more patents are filed because and to the extent that all patents function as assets and credentials. Conversely, every new patent increases the transactional asset and the signaling value of already existing patents. This network effect operates across product and technology markets. If, for example, GlaxoSmithKline attracts outside capital by advertising its rich patent portfolio, and avoids billions in taxes by paying intra-firm IP royalties to low-tax jurisdictions, Amazon and Starbucks have to adopt this strategy too and acquire patents and other IPRs in order to maximize revenues and please lenders and investors. ${ }^{100}$ The ensuing patent market can exhibit additional network effects, for the higher the liquidity of that market, the higher the utilities of all traders, attracting further capital. ${ }^{101}$ In sum, the competition for outside capital establishes links between patents and creates a transactional synchronization value, irrespective of the technology and branch concerned.

\subsection{Boundaries and Ownership of the Network}

48 Classic network products such as communication technologies that display direct network effects have precise boundaries and typically a single owner. A social media platform, for example, consists of hardware and software that is owned or at least centrally controlled by one single company, e.g. Facebook. Much less clear are, in contrast, the boundaries and the ownership of 'virtual' networks exhibiting indirect network effects. What, for example, delimits a network "of Chevrolet owners, whose relationship to each other is

\footnotetext{
${ }^{99}$ Burk (n 17).

${ }^{100}$ Amberger and Osswald (n 96), at 1; European Patent Office (n 22), at 37 ("business now sees patent rights as a financial asset").

${ }^{101}$ On network effects of financial markets see generally Economides (n 29), at 679-80.
} 
that they draw on common repair expertise", and who owns that network? ${ }^{102}$ According to Liebowitz and Margolis, such "metaphorical networks are less likely to be owned, and in some instances may not be ownable."103

49 The same seems to be true of the virtual patent network/system of a country. It consists of patentable inventions and the patents filed and granted for a particular territory. ${ }^{104}$ Neither these network nodes nor the virtual links between them are owned by a single private party. None of the numerous inventors or patent applicants/holders is able to internalize the combined synchronization value of all patents.

50 However, the conclusion that therefore no-one owns a national or regional patent system misses the point that patents are not produced and marketed by private companies. The demand-side effects discussed herein concern a 'good' that is not simply for sale but granted by patent offices on the basis of applicable patent laws. In principle, patent offices are in a position to control the attractiveness of patents. If their examination and grant procedures are designed in a way that makes the acquisition of patents burdensome and expensive, patenting races can be curbed. ${ }^{105}$ The continuous growth in patents both in absolute numbers and as measured against $R \& D$ spending and GDP illustrates, however, that efforts to this end, if any, have not been particularly successful.

51 One structural reason for the neutral if not supportive role of patent offices is that it is less burdensome for an examiner and thus the patent office as a whole to grant patents than to justify and possibly defend their refusal. ${ }^{106}$ Even more fundamental is the issue of financing patent offices. If they are funded by public, tax payer money, their organizational behavior will be oriented towards the state as the money source. If and in so far as patent offices instead rely on fees to be paid by applicants, their procedures will be designed to further the objectives of these private stakeholders, and not necessarily overall welfare. ${ }^{107}$

\footnotetext{
${ }^{102}$ Liebowitz and Margolis (n 29), at 136.

103 Ibid.

${ }^{104}$ Supra note 20.

${ }^{105}$ Bock ( $n$ 16) ("quantity, unlike quality, may actually be a solvable problem because it is easier to measure-and what can be measured can be managed").

${ }^{106}$ Hall and others (n 3), at 26-8.

107 Drahos and Braithwaite (n 73), at 204; generally North (n 47), at 73.
} 
WIPO's and other national and regional IP offices' self-conceptions are proof of this causality. They mostly or entirely finance their operations by income from fees and accordingly view themselves as providers of a 'service' that accommodates the demand of their 'clients'. ${ }^{108} \mathrm{EU}$ law and several WIPO Global Protection treaties reify this privatization of patent administration by providing that the amounts of patent fees shall be so fixed that the revenues of the offices "shall be at least sufficient" to cover their expenses but also "shall not exceed what is necessary" to this end. ${ }^{109}$

52 The fee-based, private funding of patent offices is of great importance for the horizontal network effects between patent holders explained above. Since patent offices are dependent on their clients' satisfaction, they will strive to generate as many patents with maximum autarky and synchronization value as possible. The power to control and potentially cabin the "productiveness" of offices shifts from the nation state or the assembly of contracting parties to applicants as the prime sponsors of the office. In addition, interferences from other state and non-state actors outside the patent community, i.e. applicants/patentees, patent attorneys, examiners and other staff of patent offices, are reduced to a minimum. ${ }^{110}$ The patent network is sealed off from exogenous disruptions. The more hermetic the closure, the more efficient the transactions within and thus the utility for all stakeholders. As a result, the combined interest of patentees and patent offices in the autarky and synchronization value of patents eclipses the general public interest in a functioning but not hypertrophic patent system. The virtual

\footnotetext{
${ }^{108}$ Carolyn Deere Birkbeck, The World Intellectual Property Organization (WIPO). A Reference Guide (Cheltenham: Edgar Elgar Publishing 2016), 184 (WIPO's users, member states accounting for the greatest proportion of these users and many of WIPO's staff think that "fee-paying users of WIPO's services should be viewed as the organisation's key clients"). Similarly German Patent and Trade Mark Office, Press

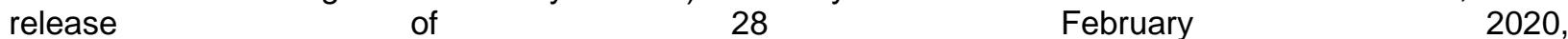
<https://www.dpma.de/english/services/public_relations/press_releases/20200228.html> accessed 21 August 2020; EUIPO, <https://euipo.europa.eu/ohimportal/en/the-office> accessed 21 August 2020 ("our core business has been the registration of EU trade marks and registered Community designs"); EPO, <https://www.epo.org/about-us/annual-reports-statistics/annual-report/2019/executive-summary.html> accessed 21 August 2020 ("Forging closer ties with users and adopting a more consultative approach in 2019 helped us to target our improvement efforts towards meeting their needs.").

${ }^{109}$ Art. 178(1) Regulation (EU) 2017/1001 of the European Parliament and of the Council of 14 June 2017 on the European Union trade mark (Text with EEA relevance. ) OJ L 154, 16.6.2017, at 1; Art. 57(4) Patent Cooperation Treaty (PCT); Art. 23(4)(b) Geneva Act of the Hague Agreement Concerning the International Registration of Industrial Designs (1999); Art. 12(4)(b) Madrid Agreement Concerning the International Registration of Marks (as amended on September 28, 1979).

110 Ingrid Schneider, Das Europäische Patentsystem (Frankfurt: Campus Verlag 2010), 188-218.
} 
patent network is controlled by the increasingly transnational patent community, not by nation states or the international community of states. Correspondingly, economic network effects, not politics, steer the system. ${ }^{111}$

\section{Conclusion}

53 Hanns Ullrich's intuition that the rise in patent numbers does not simply correlate with more innovation but with other functions of patents ${ }^{112}$ is correct. Aside from the lure of exclusionary power, the impressive growth and surprising resilience of the patent system can be attributed to a self-reinforcing network effect: The value of an individual patent increases as more patents are granted, and vice versa. The strength of this effect depends upon the degree of complementarity between individual patents and the value that their owners derive from synchronizing their acquisition and use. A relatively weak but still significant network effect operates across product and technology markets. It arises out of the complementary function of all patents to serve as financial assets and signals of success. Moderate network effects are at work between competitors who amass patents for offensive and defensive reasons. Network effects are most intense in complex technology areas, where patents are key to getting a seat at the negotiating table when standards are being set and to securing a share in the total revenue of a complex end product. All these network effects interact and support each other. Accordingly, patenting races are most acute in complex technology areas, but they also occur across the spectrum of patentable technologies.

54 To participate in these races is perfectly rational, ${ }^{113}$ for even if the autarky value of an individual patent may be very low, the increasing returns from patent synchronization values within and across product and technology markets will very often outweigh the acquisition and maintenance costs. Innovative firms cannot afford to ignore the system, patent offices depend for their existence upon the continued demand for patents, and

\footnotetext{
${ }^{111}$ Cf. European Patent Office (n 22), at 2, 30-46 ("market rules" scenario).

112 Supra note 1.

113 Contra Safrin (n 12) ("No cost-benefit calculation takes place."); Burk (n 17) ("there is no reason to believe that the observed behavior of corporations, universities, or other organizations in procuring, holding, or enforcing patents will be either coherent or rational").
} 
exogenous criticism is largely tuned out. As a consequence, and again in accordance with NE theory assumptions, economies across the globe are locked into the virtual patent network and its organizational structure. Path dependencies set in motion by every historical precedent are insufficient to explain the rigidity and expansiveness of the current patent system. ${ }^{114}$ They ultimately result from the exclusivity and fungibility of patents.

55 Let me conclude with a brief remark on the normative implications of these findings. Whereas NE theory is a powerful tool to describe and explain the operation of a country's patent system, it does not provide criteria to measure the efficiency of this virtual network. Prominent NE theorists have taken great pains to argue, but still disagree on, whether the DVORAK or the eventually adopted QWERTY typewriter keyboard is the superior network product. ${ }^{115}$ If efficiency on such a granular level cannot be convincingly established, efforts to measure the welfare effects of the virtual patent network as a whole appear futile from the beginning. ${ }^{116}$

56 Still, NE theory and institutional economics in general can contribute to the ongoing discussion about how to improve patent systems in view of their transaction costs and anticommons effects. ${ }^{117}$ Firstly, they point towards the proper question, namely "how does one reverse the increasing returns characteristics of a particular institutional matrix", i.e. cabin the network effect? ${ }^{118}$ Posing this question secondly suggests decoupling the funding of patent offices from fee income so that the public interest regains some control over the operation of the patent system. And thirdly, NE theory advises building more flexibility into the system. This aim can be achieved by expanding the options innovative firms have available if they want to appropriate innovation returns. Patent laws should allow "for a maximum of choices under uncertainty, for the pursuit of various trial methods

\footnotetext{
${ }^{114}$ Cf. North (n 47), at 95; David (n 47), at 208; Pierson (n 32), at 254.

${ }^{115}$ Cf. 'Network Goods (Theory)' (n 37), with further references.

${ }_{116}$ Compare Fritz Machlup, An economic review of the patent system (US Government Printing Office No. 15, 1958), 79-80 (no economist could possibly state with certainty that the patent system as a whole confers a net benefit or a net loss upon society) with Lemley (n 4), at 52-54 ("if the market values patents for patents' sake, ... we ought to be hesitant to disrupt that value by eliminating the patent system").

117 See, e.g., Michael A Heller, The Gridlock Economy: How Too Much Ownership Wrecks Markets, Stops Innovation, and Costs Lives (New York: Basic Books 2008), 31; Pagano (n 98); Hall and others (n 3), at 60 ("the operation of the patent system could use some improvement").

118 North (n 47), at 137-8.
} 
of undertaking activities, and for an efficient feedback mechanism to identify choices that are relatively inefficient and to eliminate them". ${ }^{119}$ In accordance with these suggestions, scholars have suggested the introduction of a "commercialization patent", granted in exchange for the commitment to make and sell a substantially novel product; ${ }^{120}$ an "inclusive patent" that reduces exclusivity from a property to a liability rule; ${ }^{121}$ and a completely new, self-tailored system of patents and other IPRs, where innovators would receive a basic level of protection and could then add more rights and legal remedies in exchange for a fee..$^{122}$

57 Proposals to reorient patent law towards a more adaptive and efficient path are therefore on the table. It is, however, not very likely that any legislature, the ultimate 'owner' of the legal foundations of the local patent system, will implement any of these proposals, for in contrast to what the European Patent Office considered a likely scenario in 2007, all virtual patent networks continue to function and none has collapsed under its own weight. ${ }^{123}$

\footnotetext{
${ }^{119}$ North (n 47), at 99.

120 Ted Sichelman, 'Commercializing Patents' (2010) 62 Stan L Rev 341.

${ }^{121}$ Geertrui van Overwalle, 'Inventing inclusive patents: From old to new open innovation' in Peter Drahos, Gustavo Ghidini and Hanns Ullrich (eds), Kritika (Cheltenham: Edward Elgar Publishing 2015), vol 1, 206. ${ }_{122}$ Abraham Bell and Gideon Parchomovsky, 'Reinventing Copyright and Patent' (2014) 113 Mich L Rev 231.

${ }^{123}$ Cf. European Patent Office, Scenarios for the Future, 2007, 44-5 (outlining such a scenario for 2025).
} 